\title{
Picosatellites for Maritime Security Applications - the Lambdasat Case
}

\author{
Georgios Mantzouris ${ }^{1,3}$, Periklis Papadopoulos², Nikitas Nikitakos ${ }^{3}$, Marco Manso $^{4}$, Alex Bordetsky¹, \\ Zacharias Sarris ${ }^{5}$, Garik Markarian ${ }^{3}$, Kyriakos Kourousis ${ }^{6,7}$
}

\begin{abstract}
This study explores the potential deployment of small satellites for maritime interdiction and security applications by investigating the available solutions and formulating a generic proposal to optimize the use of those short-lived space assets in support of these operations. The operational background is analyzed with respect to the potential use of these systems by field officers. An analysis for operational micro and picosatellite characteristics is executed, and a brief outlook on the vulnerabilities of those for Low Earth Orbits is given. Moreover, a real scenario has been implemented, and the obtained computational results provide useful insight into how these space systems can be used for maritime security operations. Particular reference is given to the state-of-the-art status of propulsion systems capable of enhancing the lifetime of the satellites. Similarly, a literature survey has been conducted collecting all available picosatellites in orbit today that deal with maritime security applications. The study also explores the application of Lambdasat picosatellite (currently in orbit) to demonstrate the capability of exchanging alert messages between ground stations in Greece and in the US and vessels in the middle of the ocean. With these experiments we will demonstrate the ability magnitude of a picosatellite to support maritime operations.
\end{abstract}

KEYWORDS: Microsatellites, Picosatellites, Space maritime security operations, Micropropulsion, Vulnerabilities, Satellite communication, Picosatellite ground station.

\section{INTRODUCTION}

\section{THE OPERATIONAL MARITIME DIMENSION}

Contemporary maritime security operations cover a full range of different missions. As outlined in the European Union Maritime Security Strategy (Bordetsky and Netzer 2010), adopted in June 2014, they encompass protection of critical maritime infrastructure (e.g. ports and port facilities, off-shore installations, energy supply by the sea, and underwater pipelines), preservation of freedom of navigation (including security of crew and passengers against piracy) as well as prevention and countering cross-border illegal activities (such as human trafficking and illegal transportation of dangerous materials and substances). In order to be effective, modern maritime security operations require a variety of different applications, multiple information sources and technological frameworks. In addition, a real-time infrastructure allowing to combine them into cost-effective intelligence schemes would dramatically decrease response time and, as a result, increase mission efficiency. However, such infrastructure is still absent from today's operational and tactical maritime environment.

Maritime security missions cover a vast environment where satellites play an important role in exchanging information and contributing to the creation of shared situational awareness between force's elements. Satellites can provide imagery and communications services, the latter also enabling bidirectional information exchange with civilian entities (e.g. commercial ships).

This paper is part of a work that explores the application of small satellites, also called PicoSats, CubeSats or picosatellites, 
to assist security maritime operations, including surveillance, antipiracy as well as search and rescue operations. The interest in picosatellites is rising given their relative low cost (development and launch), relative ease of engineering, and available wide range of off-the-shelf equipment (Bordetsky and Dougan 2008).

In our work, we will conduct experiments that resort to the Lambdasat picosatellite, being the main objectives the global transmission and dissemination of information between ground stations and ships. We present our reasoning on the relevance of picosatellites for purposes of maritime security; then we describe the Lambdasat, a recently deployed picosatellites that we will use for our experiments on maritime security. We also describe our initial acquired data related with maritime experiments based on picosatellites, which includes message specifications and installations of the ground control station. Thus we finalize by presenting the way ahead.

Historical background on the use of micro and minisatellites for maritime applications has been extensively given in, taking into account that, back in 1990s, the idea was very primitive and only very large space institutions had the capability to incorporate space into the maritime arena. Today very small satellites are accessible from universities and research organizations and, due to the miniaturization of the technology, more people has access to space. The use of space for maritime security is still an area where research is growing very fast, taking into account that $80 \%$ of Earth's goods are being transferred via sea. Therefore sea commerce and sea transportation is a major pilar of global market and that is why space maritime security is becoming more and more a field at which research is being fast directed.

Finally another important aspect that is being addressed in this paper is a detailed literature survey on the institutions that are conducting research initiatives in the areas of micropropulsion for very small to picosatellite buses. A micropropulsion thruster installed on board a picosatellite bus could raise the lifetime of it from one to two months to maybe six months up to five years (rough estimation). Research is still ongoing in various organizations and is needed in order to prove what will be the exact number of the effectiveness of a microthruster on board a picosatellite. It has been verified though and is under the main objectives of this research study that the most suitable microthruster for picosatellites is an electrothermal thruster for many different advantages that it encompasses. That is why today there are very few universities to undergo this type of research aiming to find a propulsion solution for these very cost-effective picobuses.

\section{VULNERABILITIES OF PICOSATELLITES IN VERY LOW EARTH ORBITS}

Before we start our analysis, we should mention that our Lambdasat picosatellite is orbiting in 380 to $420 \mathrm{~km}$, directly below of the International Space Station. Due to orbital decay and after approximately one year of orbital life, the satellite will be deorbited due to NASA requirements. In this altitude, though, there are some vulnerabilities that need to be addressed so the reader can understand the environment parameters. In summary the issues that need to be accounted in designing a microsatellite mission aiming to support maritime security operations with respect to altitude are:

- The effect of electrons and protons in Van Allen radiation belts on the survivability of satellites when they are passing through that zones.

- The identification of the major risk areas inside Van Allen belts (especially in polar horns).

- The implications on satellite's body from the atomic oxygen in North Pole (the aurora borealis).

- The effect of the atmospheric density near the mirror points of trapped particles on the satellite's orbit.

- The effect of the 11 or 22-year solar cycle on the magnetosphere of Earth and as an aftermath ionizing procedure in Low Earth Orbits (LEO).

- The vulnerabilities that a LEO satellite can withstand from ionizing particles coming from Earth's ionosphere (e.g. how heavy ions in LEO affect satellites materials, such as aluminum, titanium, polymers etc.).

- The necessary material properties and dimensions (thicknesses) in accordance with Very Low Earth Orbit (VLEO) in order to avoid particle penetration procedures and finally charging of satellite.

- The effect of solar ultraviolet (UV) radiation into LEO through ionization of magnetosphere and the density of trapped particles.

- The effect of deep dielectric charging on a satellite (LEO antiproton radiation belt) (Gordon and Morgan 1993).

\section{PICOSATELLITE OPERATIONAL CHARACTERISTICS}

The list of all operational characteristics of picosatellites is being reported in Mantzouris et al. (2015). All these characteristics may seem highly tactical or operational, but if one analyzes the effects that are going to affect the execution of operations, then the results can be consider strategic. 
To sum up though the operational part, one needs to have in mind the following attributes of the picosatellite system. The approximate total time that we have during a whole day to communicate through a system that has four satellites (the cost will be around $50000 €$ approximately) is 120 minutes (Universität Würzburg 2015) (two hours during the day). Therefore the total gap time between consecutive satellites which passes during one day is approximately 22 hours (Universität Würzburg 2015). However, with this amount of timeframe, we have the capability to exchange the needed information with a merchant vessel underway and feed the important information required for a safe and secure transit from a high-risk area. Modern maritime threats, as they appear on the international scene today, do not require 24/7 hours of communication with fusion centers ashore, but only a logical timeframe sufficient to transfer critical information back and forth and secure future courses of action.

For example and taking into account information collected from open internet as well as official satellite companies sources for pricing and policy with subscribers, we can have the following case. If we have available $1,000,000 €$ and we charge $1 \$$ per minute (best rate), it means $1,000,000 \mathrm{~min} / 60 \mathrm{~min}$ per hour $=16,666.66$ hours of selling time/24 hours per day $=694$ days for returning the money back (this is only for telephone - worst case scenario) or 450 subscribers to pay $200 €$ per month $=90,000 € \times 12$ months $=1,080,000 €$ per year (a ship-owner pays approximately $10,000 €$ per month for one ship for satellite communication services).

We can easily see in Table 1 what a micro or picosatellite can provide to the customers taking into account how many satellites we have in orbit concurrently and how many hours they can cover. As one can see (and this is only an indicative scale table), the services are numerous and can extent to as many users as the bandwidth allows. A general rule is that a picosatellite can facilitate throughput up to $1.5 \mathrm{Mbps}$. Finally, in the last row of Table 1, pricing in approximate numbers is shown giving a rough indication of how much one or 12 picosatellites can cost to be in orbit (all inclusive).
On the other hand, Table 2 provides a generic/indicative representation of mini/femto satellite can alter its mass and cost as well as altitude and project lifetime in accordance with current technological trends and figures. Picosatellites (red coloured row) can stay up in orbit for up to two years (with no propulsion scheme) and the cost is $160 \mathrm{~K} \$$ per $1 \mathrm{~kg}$ (this is the maximum cost - a mean cost, as it has been referred previously, is up to $100 \mathrm{~K} \$$, all inclusive).

To date, all available picosatellites (with weight less than $1 \mathrm{~kg}$ ) are listed in Table 3. Satellites that have weight greater than $1 \mathrm{~kg}$ are listed in this table for comparison purposes.

\section{THE LAMBDASAT CONCEPT}

The Lambdasat team formed in the Summer 2012 under the guidance and leadership of Professor Periklis Papadopoulos from San Jose State University, in California, and, with his strong affiliation with NASA Ames Research Center, initiated

Table 1. Services via number of picosatellites that can be provided (pricing in approximate numbers).

\begin{tabular}{|c|c|c|c|c|c|c|}
\hline \multirow{2}{*}{ Services } & \multicolumn{7}{|c|}{ Satellites } \\
\cline { 2 - 8 } & $\mathbf{1}$ & $\mathbf{2}$ & $\mathbf{4}$ & $\mathbf{8}$ & $\mathbf{1 6}$ & $\mathbf{2 4}$ \\
\hline Coverage & $0.5 \mathrm{~h}$ & $1 \mathrm{~h}$ & $2.5 \mathrm{~h}$ & $\mathbf{7 h}$ & $14 \mathrm{~h}$ & $24 / 7$ \\
\hline $\begin{array}{c}\text { Video streaming } \\
\text { Voice }\end{array}$ & & & & $\mathrm{X}$ & $\mathrm{X}$ & $\mathrm{X}$ \\
\hline Telephone & & & & $\mathrm{X}$ & $\mathrm{X}$ & $\mathrm{X}$ \\
\hline $\begin{array}{c}\text { Email exchange } \\
\text { Internet }\end{array}$ & $\mathrm{X}$ & $\mathrm{X}$ & $\mathrm{X}$ & $\mathrm{X}$ & $\mathrm{X}$ & $\mathrm{X}$ \\
\hline $\begin{array}{c}\text { Real-time ship } \\
\text { tracking }\end{array}$ & $\mathrm{X}$ & $\mathrm{X}$ & $\mathrm{X}$ & $\mathrm{X}$ & $\mathrm{X}$ & $\mathrm{X}$ \\
\hline Oriented missions & $\mathrm{X}$ & $\mathrm{X}$ & $\mathrm{X}$ & $\mathrm{X}$ & $\mathrm{X}$ & $\mathrm{X}$ \\
\hline Land tracking & $\mathrm{X}$ & $\mathrm{X}$ & $\mathrm{X}$ & $\mathrm{X}$ & $\mathrm{X}$ & $\mathrm{X}$ \\
\hline Photo streaming & $\mathrm{X}$ & $\mathrm{X}$ & $\mathrm{X}$ & $\mathrm{X}$ & $\mathrm{X}$ & $\mathrm{X}$ \\
\hline Personal satellite & $\mathrm{X}$ & $\mathrm{X}$ & $\mathrm{X}$ & $\mathrm{X}$ & $\mathrm{X}$ & $\mathrm{X}$ \\
\hline Pricing $(€)$ & $100 \mathrm{~K}$ & $200 \mathrm{~K}$ & $400 \mathrm{~K}$ & $800 \mathrm{~K}$ & $1.6 \mathrm{M}$ & $2.4 \mathrm{M}$ \\
\hline
\end{tabular}

Table 2. Generic representation of satellites with respect to cost and mass.

\begin{tabular}{|c|c|c|c|c|c|}
\hline & Mass $(\mathrm{kg})$ & Altitude $(\mathbf{k m})$ and orb period $(\mathrm{h})$ & Project lifetime (years) & Total cost (M\$) & Cost/mass (K\$/kg) \\
\hline Mini & $100-500$ & $1,000-5,000(2-3 \mathrm{~h})$ & $4-7$ & $10-150$ & 200 \\
\hline Micro & $10-100$ & $500-2,000(1.6-2 \mathrm{~h})$ & $2-5$ & $1-30$ & 400 \\
\hline Nano & $1-10$ & $300-800(1.4-1.7 \mathrm{~h})$ & $2-3$ & $0.1-10$ & 800 \\
\hline Pico & $0.1-1$ & $200-400(1.4-1.5 \mathrm{~h})$ & $1-2$ & $0.05-2$ & 160 \\
\hline Femto & $<100 \mathrm{~g}$ & $200-400(1.4-1.5 \mathrm{~h})$ & 1 & $<0.05$ & 320 \\
\hline
\end{tabular}


Table 3. General representation of all amateur satellites in orbit that are under a minisatellite weight frame and are being able to be received from the University of the Aegean ground station that has been built for the Lambda picosatellite.

\begin{tabular}{|c|c|c|c|c|c|c|c|}
\hline Satellite & Operator & Launch & $\begin{array}{c}\text { Weight } \\
\text { [kg] }\end{array}$ & $\begin{array}{c}\text { Power } \\
\text { [W] }\end{array}$ & $\begin{array}{c}\text { Transmission } \\
\text { power }(\mathrm{W}]\end{array}$ & Orbit [km] & Experiment \\
\hline LO-19 (LUSAT) & Amsat Argentina & 1990 & 13.76 & - & - & $\begin{array}{c}\text { Sun } \\
\text { synchronous } \\
\text { near polar LEO }\end{array}$ & $\begin{array}{l}\text { CCD camera for Earth } \\
\text { photography }\end{array}$ \\
\hline FO-29 (JAS-2) & $\begin{array}{l}\text { Japan Aerospace } \\
\text { Agency }\end{array}$ & 1996 & 50 & 10 & 1 & Polar orbit 1,200 & $\begin{array}{l}\text { Sun sensor, geomagnetism } \\
\text { sensor, magnetorquer, data } \\
\text { processor and GaAs solar cells }\end{array}$ \\
\hline $\begin{array}{c}\text { RS-22 (Mozhayets } \\
4)\end{array}$ & $\begin{array}{l}\text { Moscow Military } \\
\text { Academy }\end{array}$ & 2003 & 64 & - & - & 670 & $\begin{array}{l}\text { Glonass navigation and laser } \\
\text { geodetic measurements }\end{array}$ \\
\hline RS-40 (MiR) & $\begin{array}{c}\text { Siberian State } \\
\text { Aerospace University }\end{array}$ & 2012 & 65 & - & - & 1,500 LEO & $\begin{array}{l}\text { AOCs for small satellites, Earth } \\
\text { observation camera and others }\end{array}$ \\
\hline CO-57 (XI-IV) & $\begin{array}{l}\text { Intelligent Space } \\
\text { Systems Lab - } \\
\text { University of Tokyo }\end{array}$ & 2003 & 1 & 8 & $800 \mathrm{~mW}$ & 800 & - \\
\hline CO-58 (XI-V) & $\begin{array}{l}\text { Intelligent Space } \\
\text { Systems Lab - } \\
\text { University of Tokyo }\end{array}$ & 2005 & 1 & 8 & $800 \mathrm{~mW}$ & 700 & New types of solar cells \\
\hline $\begin{array}{c}\text { CO-65 } \\
\text { (CUTE1.7+APDII) }\end{array}$ & $\begin{array}{l}\text { Tokyo Institute of } \\
\text { Technology }\end{array}$ & 2008 & 2 & 4 & $80 \mathrm{~mW}$ & 630 & Photodiode sensor module \\
\hline COMPASS-1 & University of Aachen & 2008 & 0.85 & 1 & - & 600 & GPS, Camera color images \\
\hline CO-66 (SEEDS-II) & Nihon University & 2006 & 1 & 1.6 & $90 \mathrm{~mW}$ & 620 & - \\
\hline RS-30 (Yubileiniy) & $\begin{array}{l}\text { Moscow Military } \\
\text { Academy }\end{array}$ & 2008 & 45 & - & - & - & GPS, Glonass combination \\
\hline $\begin{array}{c}\text { PRISM } \\
\text { (HITOMI) }\end{array}$ & $\begin{array}{l}\text { Intelligent Space } \\
\text { Systems Lab - } \\
\text { University of Tokyo }\end{array}$ & 2009 & 8.5 & 8 & $800 \mathrm{~mW}$ & 660 & Remote sensing \\
\hline $\begin{array}{c}\text { STARS } \\
\text { (KUKAI mother) }\end{array}$ & Kagawa University & 2009 & 4.2 & 8 & 3.8 & 666 & Space tethered robotic satellite \\
\hline $\begin{array}{c}\text { STARS } \\
\text { (KUKAI daught) }\end{array}$ & Kagawa University & 2009 & 3.8 & 8 & 3.8 & 666 & Space tethered robotic satellite \\
\hline $\begin{array}{c}\text { KKS-1 } \\
\text { (KISEKI) }\end{array}$ & $\begin{array}{l}\text { Tokyo Metropolitan } \\
\text { College of Industrial } \\
\text { Technology }\end{array}$ & 2009 & 3 & - & - & 636 & $\begin{array}{c}\text { Microthrusters and camera to } \\
\text { Earth imaging }\end{array}$ \\
\hline SwissCube-1 & University of Lausanne & 2009 & $<1$ & 1.5 & - & $\begin{array}{l}720 \text { Sun } \\
\text { synchronous } \\
\text { near circular } \\
\text { polar }\end{array}$ & On-board telescope \\
\hline ITU-pSat1 & $\begin{array}{l}\text { Istanbul Technical } \\
\text { University }\end{array}$ & 2009 & 0.99 & 1 & $20 \mathrm{~mW}$ & 723 & On-board CMOS Camera \\
\hline HO-68 (XW-1) & China Amateurs & 2009 & 50 & 21 & $200 \mathrm{~mW}$ & $\begin{array}{l}\text { 1,200 Sun } \\
\text { synchronous }\end{array}$ & On-board CMOS Camera \\
\hline TIsat-1 & $\begin{array}{l}\text { University of Applied } \\
\text { Sciences of Southern } \\
\text { Switzerland }\end{array}$ & 2010 & $<1$ & - & - & 635 & Atomic oxygen experiment \\
\hline Jugnu & $\begin{array}{c}\text { Indian Institute of } \\
\text { Technology }\end{array}$ & 2011 & 3 & 3.8 & - & 860 & Microimaging and GPS \\
\hline MaSat-1 (MO-72) & $\begin{array}{l}\text { BME Hungarian } \\
\text { University }\end{array}$ & 2012 & $<1$ & $\begin{array}{c}1.2 \\
-2.2\end{array}$ & $400 \mathrm{~mW}$ & Circular 574 & $\begin{array}{l}\text { ESA Comms Exps and } \\
\text { on-board camera }\end{array}$ \\
\hline
\end{tabular}


Table 3. continuation...

\begin{tabular}{|c|c|c|c|c|c|c|c|}
\hline Satellite & Operator & Launch & $\begin{array}{l}\text { Weight } \\
\text { (kg] }\end{array}$ & $\begin{array}{c}\text { Power } \\
\text { [W] }\end{array}$ & $\begin{array}{c}\text { Transmission } \\
\text { power }(\mathbf{W}]\end{array}$ & Orbit [km] & Experiment \\
\hline Horyu-2 & University of Kyushu & 2012 & 7.5 & 2.7 & 1 & $\begin{array}{c}\text { Sun } \\
\text { synchronous } \\
680\end{array}$ & $\begin{array}{l}\text { 300-V photovoltaic power } \\
\text { generation in LEO }\end{array}$ \\
\hline AIST-2 (RS-43) & $\begin{array}{c}\text { Russian Samara } \\
\text { Aerospace University }\end{array}$ & 2013 & 39 & 15 & - & - & Measure of geomagnetic field \\
\hline SOMP & $\begin{array}{c}\text { Dresden University } \\
\text { of Technology }\end{array}$ & 2013 & 1 & 2 & - & 550 & Atomic oxygen experiments \\
\hline BEESAT-2 & $\begin{array}{l}\text { Technical University of } \\
\text { Berlin }\end{array}$ & 2013 & 1 & 0.5 & - & 550 & $\begin{array}{l}\text { Reaction wheels for } \\
\text { picosatellites }\end{array}$ \\
\hline EstCube-1 & $\begin{array}{c}\text { Estonian Tartu } \\
\text { University }\end{array}$ & 2013 & 1.05 & 3.6 & 0.5 & 660 & Micropropulsion \\
\hline ZACube-1 & $\begin{array}{l}\text { French South African } \\
\text { Institute of Technology }\end{array}$ & 2013 & 1.2 & - & 1 & 620 & - \\
\hline Triton-1 & ISIS BV Dutch & 2013 & 2.5 & 4 & - & 650 & AIS sensor \\
\hline Humsat-D & University of Vigo & 2013 & 1 & 3 & - & 610 & Arctic details \\
\hline UWE-3 & $\begin{array}{l}\text { University of } \\
\text { Wurzburg }\end{array}$ & 2013 & 1 & - & - & 650 & $\begin{array}{l}\text { Attitude determination for } \\
\text { picosatellites }\end{array}$ \\
\hline IPEX & NASA JPL Cal Poly & 2013 & 1.5 & 10 & 1 & 700 & $\begin{array}{l}\text { Validate experiments for future } \\
\text { Earth orbits }\end{array}$ \\
\hline AIST-1 (RS-41) & $\begin{array}{c}\text { Russian Samara } \\
\text { Aerospace University }\end{array}$ & 2013 & 53 & - & - & 575 & 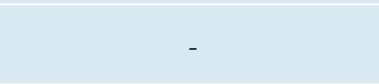 \\
\hline SPROUT & Nihon University & 2014 & 7.1 & - & $450 \mathrm{~mW}$ & 628 & Orbital membrane - sail \\
\hline NanosatC-Br1 & $\begin{array}{c}\text { National Institute of } \\
\text { Space Research - Brazil }\end{array}$ & 2014 & 1 & - & - & 615 & $\begin{array}{l}\text { South Atlantic anomaly } \\
\text { measure }\end{array}$ \\
\hline POPSAT-HIP1 & Singapore Nanosatellite & 2014 & 3 & - & - & 620 & - \\
\hline ANTELSat & $\begin{array}{c}\text { Universidad ORT } \\
\text { Uruguay }\end{array}$ & 2014 & 2 & - & - & 650 & - \\
\hline PolyITAN & $\begin{array}{l}\text { National Technical } \\
\text { University - Ukraine }\end{array}$ & 2014 & 1 & - & - & 620 & - \\
\hline AISSat-1 & $\begin{array}{l}\text { German Aerospace } \\
\text { Center }\end{array}$ & 2014 & 14 & 15 & - & 660 & Maritime tracking \\
\hline VesselSat1 & ORBCOMM & 2011 & 29 & - & - & 810 & Maritime tracking \\
\hline VEsselSat2 & ORBCOMM & 2012 & 28 & 6 & - & 440 & Maritime tracking \\
\hline IO-26 (ITAMSAT) & Italy & 1993 & 11.2 & - & - & 800 & Amateur comms \\
\hline CO-55 (CUTE-I) & $\begin{array}{l}\text { Tokyo Institute of } \\
\text { Technology }\end{array}$ & 2003 & 3 & 3 & $350 \mathrm{Mw}$ & 800 & 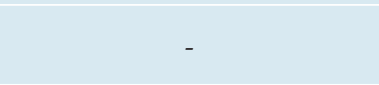 \\
\hline O/OREOS & NASA & 2010 & 5.5 & - & - & 630 & - \\
\hline AENEAS & USA & 2012 & 4 & - & - & 600 & - \\
\hline CubeBug-1 & $\begin{array}{l}\text { Argentinian Ministry } \\
\text { of Science }\end{array}$ & 2013 & 1 & - & - & 600 & - \\
\hline CUSat-1 & Cornell University & 2013 & 23 & - & - & 600 & - \\
\hline PhoneSat2.4 & $\begin{array}{l}\text { NASA Ames Research } \\
\text { Center }\end{array}$ & 2013 & 1 & - & - & 600 & - \\
\hline $\begin{array}{l}\text { CubeBug-2 } \\
\text { (LO-74) }\end{array}$ & $\begin{array}{l}\text { Argentinian Ministry } \\
\text { of Science }\end{array}$ & 2013 & 2 & - & - & 600 & - \\
\hline
\end{tabular}

this work in order to design and built a picosatellite under the name of the Greek letter "Lambda" ( $\Lambda \alpha \mu \beta \delta \alpha)$, which historically comes from the " $\Lambda$ " of Lakedemons from Sparti and the "L" letter from the Greek word "E $\lambda \lambda \eta \nu \varepsilon \varsigma$ ” (“Greeks”).
The concept of the mission is to evaluate the use of picosatellites in maritime security operations, supporting especially counter piracy actions (commercial and/or military) and generally provide deterrence for maritime terrorism in the 
global commons. An overview of the various components of the LambdaSat is provided in Fig. 1.

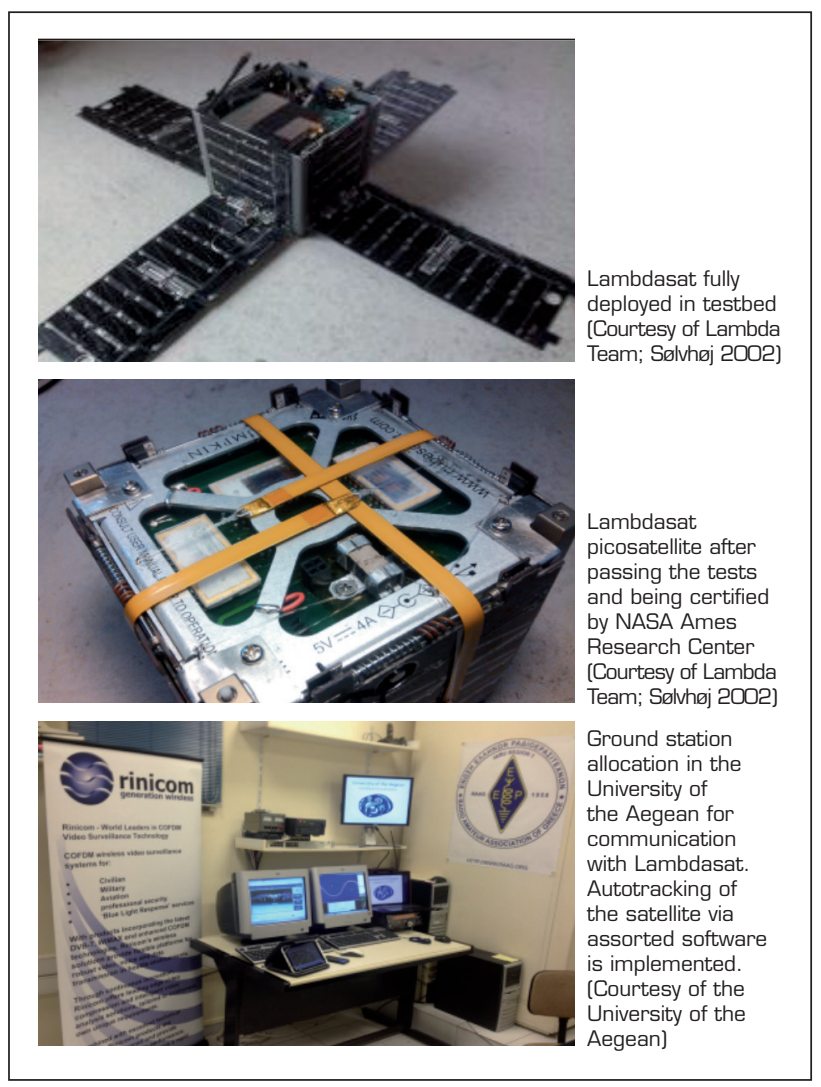

Figure1. Lambdasat components and ground station.

\section{AIM}

The aim of the picosatellite project was to:

- Evaluate the use of nano and picosatellites (in this case, via Lambdasat) in maritime security, supporting especially counter piracy operations, and generally provide deterrence for maritime terrorism in the global commons.

- Promote space innovation and boost space knowledge as well as new ideas to the Greek space technological arena. Besides to carry out joint research towards the design and launch of "LambdaSat".

- Exchange general scientific knowledge among partners.

- Enhance fruitful cooperation among relevant students of the aforementioned university departments, under Professor's supervision and guidance.

- Train postgraduate and doctoral students in procedures and techniques relevant to the use of microsatellites for maritime security environment.
- Make publicly available that maritime security operations can be supported from microsatellites with low-cost applications and create a framework for merchant mariners to have a near real-time operational support during their transiting through high-risk areas.

- Promote interest in the teaching and research activities of the respective institutions.

- Deepen the understanding at each institution of the economic, space engineering as well as cultural and social engineering ethics.

- Promote faculty and institutional exchanges where feasible by inviting faculty and staff of the partner institutions to participate in a variety of teaching and/ or research activities and professional development in space systems field area.

- Exchange information pertaining to developments in teaching, student development and research at each institution - and publish the results.

- Sustain the motto that "The real future is the ideas waiting to come true and enlighten the endeavors towards perfection".

\section{UNIVERSITY OF THE AEGEAN'S ROLE}

University of the Aegean is the designer for space maritime security risk assessment methods and analysis through the satellite. Specifically the strategic and operational objectives of the satellite with respect to maritime security are as follows.

\section{Strategic Objectives}

- Evaluate the use of nano and picosatellites in maritime security.

- Provide deterrence for maritime terrorism in the global commons.

- Provide merchant mariners with low-cost near real-time operational support during their transiting through high-risk areas.

\section{Operational Objectives}

- Experiment automatic identification system (AIS) implementation in maritime security operations.

- Support counter piracy - armed robbery operations through various methods of communication to merchant mariners (text, audio, video etc.). 
- Create Merchant Marine Risk Assessment Indexes: methodologies to effectively counter piracy - armed robbery through space microassets (such as Lambdasat).

- Operational support to armed guards on board the merchant vessel on a near real-time frame.

- Conduct measure of effectiveness and performance studies and determine the way ahead.

- Conduct feasibility study and implement a cost-effective analysis for inserting picosatellites in the maritime security arena.

- Utilize a ground station in Greece(University of the Aegean).

- Conduct studies for measures of effectiveness (MOEs), measures of performances (MOP), and cost-benefit analysis (CBA) as well as risk assessment.

- Exchange data from the satellite ground stations to a merchant vessel transiting through the high-risk area.

- Measure the operational effectiveness to support counter piracy - armed robbery in the high-risk areas (postorbit).

- Measure risk assessment factors change with the use of picosatellite for merchant mariners transiting highrisk areas (postorbit).

The partners of the project (relevant to the scope of this paper) come from different organizations/universities as follows:

- $\quad$ San Jose State University (SJSU): Professor Periklis Papadopoulos - principal investigator.

- University of the Aegean (UOA): Professor Nikitas Nikitakos - Shipping - AIS - counter piracy.

\section{LAMBDASAT SUCCESSFUL LAUNCH - OFFICIAL ANNOUNCEMENT OF NASA}

For historical purposes it is here where we refer the milestones that Lambdasat mission managed to perform even in an era of major economic crisis.

We quote the official announcement of NASA for the successful launch of Lambdasat picosatellite. This endeavor was a tremendous milestone for the Hellenic annals since it is the first mission ever built only by Greeks and launched from the International Space Station (Takao and Ono 2004).

\section{NASA MISSION JUSTIFICATION}

NASA has supported the whole mission from the beginning and, with the sole support of Professor Periklis Papadopoulos (San Jose State University), the justification was to "support merchant shipping in countering maritime piracy in oceanic as well as in littoral sea environment. In parallel, provide merchant mariners with near real time cost effective information such as text, video, audio, images etc. in order to proactively counter the maritime piracy threat during transiting in high risk areas". Under this statement, the whole mission started in Summer 2012, and the satellite was set in orbit from the International Space Station by the end of February 2015 (February $24^{\text {th }}$ ). A mission statement was also produced in order for all to get acquainted with the expectations, and this is herein referred as follows.

\section{PIRACY BACKGROUND (THREAT)}

As it has been seen in the last years, piracy is an ongoing phenomenon that has drawn global attention. The United Nations Contact Group of Somalia (UNCGPCS), the North Atlantic Treaty Organization (NATO) Operation Ocean Shield, the European Union mission EU NAVFOR Atalanta along with US, Chinese, Indian, and Iranian maritime forces (via patrolling vessels in the area of Gulf of Aden) have special interest in contributing to the diminishing of the phenomenon by safeguarding with military vessels the high-risk area. High-risk areas are considered to be Indian Ocean, Gulf of Aden, Gulf of Oman, West Africa oceanic area and broad area of Gulf of Mexico and the Central America. It is worth noting that, even if piracy is diminishing in the Indian Ocean, it is increasing in West Africa areas.

\section{CURRENT SITUATION [WEAKNESSES)}

The current status is that, if a piracy incident happens, the merchant mariners have only one way of communication with operational ashore headquarters, which is UKMTO or national authorities. This is conducted mainly via Inmarsat satellite service, which is a very costly mean of communication ( $1 \mathrm{~min}$ of communication costs around \$ 100 or, for downloading $1 \mathrm{MB}$ of data, it costs $80 €$ ), or via VHF when near shoreline (up to $16 \mathrm{~nm}$ ).

The most important aspect is that pirates are travelling throughout a vast oceanic area which is, in this case, Indian Ocean, Gulf of Aden, Gulf of Oman, and Bab El Mandeb straits, and the captain of the merchant vessel has not prominent or instant communication path in order to get informed on a regular basis (on a near real-time frame) for the new positions of incidents or pirates that are in the area.

Currently, there is no satellite support to merchant mariners that will feed them with crucial tactical information such as recent piracy incidents or pirate action groups that are active in the area. So, with Lambdasat satellite, the captain and the 
team leader (guard) on board a merchant vessel will eventually know what is happening around their ship not in a range of 40 miles (range of conventional sensors like radars), but at longer distance and with a capability of knowing every 40 min what is happening in a circular range around the ship (positive identification of up to 200 miles). This will give the capability to be proactive and not psychologically stressed for what is going to happen in the next hours of sail. The only information that they have now is only through TELEX from UKMTO, which is rare, and every $24 \mathrm{~h}$.

In the last two years, NATO is seeking for cost-effective solutions to deal with the piracy problem in order to use as few ships as possible, patrolling the area of operations. There is a desire for moving into a cost-effective network-centric operational scheme in order to utilize patrolling assets only when necessary and not in a continuous basis. The continuous use of military vessels is costly for the nations, as well as not very effective since they have to be at sea for long times waiting to respond to an incident. By giving the capability for the merchant mariners to have updates every $40 \mathrm{~min}$, they can act proactively and at the same time by using the satellite they can send us back to the real situational awareness data around their area of operation. Therefore military vessels could be stationed on a littoral position ready to deploy their assets, when needed, only patrolling outside pirate camp areas and creating a type of unofficial embargo for their actions.

\section{WAY AHEAD [OPPORTUNITIES/STRENGTHS)}

First and foremost, it is important to note that we try to inform a merchant vessel mariner on board a vessel in the middle of the ocean on a near real-time scheme (eventually every $40 \mathrm{~min}$ that the microsatellite Lambdasat will pass over the same area). This will give it the capability to have on-hand information on recent piracy incidents at least every $40 \mathrm{~min}$ and at very low cost.

Additionally, implementing a space AIS capability we deliver to the mariners another very helpful piece of critical information. The merchant mariners now have relevant AIS information which reaches distances of up to $20-30$ nautical miles through an Earth signal. By providing the capability of receiving space AIS info in the middle of the ocean (in distances up to 200 nautical miles around them - potential footprint of the satellite), they have at least a primitive indication which are the non-suspect vessels during the next hours of transiting. AIS is a system that is required from International Maritime
Organization (IMO) for all vessels above 300 tonnes. So if the merchant mariner has received AIS information for a vessel (that means it is more than 300 tonnes), he knows directly that the vessel is not a pirate skiff, dhow or generally a suspect boat. Therefore he does not have to wait to have this verification until he has a visual contact with the vessel (this is the case happening today).

NATO has a special interest on counter piracy operations, and it has been reported and noted in the last two years that, even though piracy is decreasing as a phenomenon in the Indian Ocean, it is being increased in other areas like West Africa with recent incidents up to 150 miles from shore. The support and escorting operations is a status in the Gulf of Aden and Somali Basin area and especially through the International Transit Corridor. Russia, China, India, and US are providing this kind of escort throughout the Indian Ocean, if asked and at the same time they consume a lot of money. It will be much more costeffective if we have systems on board the merchant vessels that would receive information from a center shore, which would feed them with near real-time information in order for them to get prepared and more proactive. Of course this link could be used vice versa for situational awareness. Another aspect is that the merchant vessel has always live and fresh information for suspect vessels that now is being missed. Nobody has the capability of transferring back this information. With Lambdasat capability, the merchant mariner will send this information every 40 min back to the center from the middle of the ocean (either data up to $300 \mathrm{~kb}$, or voice, video, images etc.). This system will also work in littoral transiting and passages and in territorial waters (less than $40 \mathrm{~nm}$ ).

Last but not least, the use of a microcamera on board a microsatellite would give the opportunity to the center shore (e.g. SJSU Maritime Operational Center - MOC) to distinguish among large cargo ships and small skiffs, dhows or other suspect vessels that are now invisible in the oceanic areas. With this capability, the pirates would be very difficult to hide and at the same time the merchant mariners would have a first-hand response on pirate activities and a much more safe passage through the high-risk areas.

\section{OVERALL MISSION OBJECTIVES}

- Give the capability to the merchant mariners to receive updated piracy or maritime terrorism information that now is limited only to very little information (continuous IMO request). 
- Relay piracy incidents report to merchant mariners in a near real-time frame (every $40 \mathrm{~min}$ ). Today it is rare, random and in the best case via TELEX every $24 \mathrm{~h}$.

- $\quad$ AIS implementation will increase vigilance and alertness in distances up to Lambdasat footprint (tentatively 200 miles).

- Information to MOC from all merchant vessels (MVs) in the area and the capability of the MOC to collect critical information that today is being done only via Inmarsat phone by voice or by text emails.

- Diminish the cost of the communication to the necessary and not charge huge amounts of money only for $1 \mathrm{MB}$ of data for merchant marines communication (Inmarsat case).

- Give NATO (and nations) the capability to decrease military vessels in the area not patrolling continuously the high seas, but being stationed in a dynamic waiting area where assets will be ready to assist upon request from MVs.

\section{COMMUNICATION SCHEME - CHARACTERISTICS}

\section{Concept}

UOA, in conjunction with other partners, will provide a real scenario, which is going to be executed during the flight mission. The scenario is going to be built initially on a conceptual basis, SJSU will verify its compatibility with the satellite's characteristics and then the whole scenario is going to be tested via STK software. The instructions to incorporate experiments to be tested during flight time are as follows:

- Data will be send from SJSU to Lambda satellite and then to a merchant vessel. This data should be received via cell phone on board the merchant vessel (open sea/ coastline/port areas).

- Send and receive data from mobile ground station to the merchant vessel, acting as shore advisory team to the ship (command and control mobile center).

- Measure the overall effectiveness of network, communication, latency times among end users, weather data influence and other important factors. All these areas are going to be specified in upcoming meetings to finalize the exact priorities.

- Include voice in transmission if possible (these two factors are extremely helpful and supportive to maritime security issues).
- If a camera is going to be incorporated, then a transfer of a satellite image to the ground station or to the vessel should be of great importance for maritime safety purposes. Analyze the operational use of images received from VLEO satellites (there is no camera on board the Lambdasat but this feature is going to be implemented in the next picosatellite mission).

- UOA ground station team will transmit a text-type document of maritime security critical factors to a merchant vessel underway. These critical factors are going to be the major factors that influence the survivability of the ship when transiting through the high-risk area. The document has been prepared from UOA and in accordance with the communication specifications from the SJSU.

- During the analysis and research, the following research items would consider:

a. Specifications of the communication equipment on board merchant vessel (UOA). This can happen only after receiving the exact communication scheme for the satellite from the SISU.

b. Ways (if needed) on how this communication/ software can be modified (if needed) in order to transmit the available data to the merchant vessel or to the other ground stations in Greece (SJSU).

c. Available throughput/bandwidth of the Lambda satellite (SJSU).

d. Ground station in Greece should be mobile (small antenna and a computer-based system).

e. Incorporate an AIS approach to the satellite bus. An AIS sensor can be installed in the satellite to receive AIS signals from the ships. All ships with tonnage greater than 300 tonnes need to have installed on board an AIS transmitter to transmit their positions to a shore station (IMO regulation). ORBCOMM in the US has launched the first satellite with implementation of a satellite AIS sensor on board its satellite bus. Further research is needed if this is an option. UOA is going to implement this type of search and provide more information to the principal investigator, if asked.

f. Send a message from UOA ground station to a merchant vessel bridge via Iridium communication and the Lambdasat to a mobile phone (Iphone, 
blackberry-type). The message will be a text with tables, word document and some images.

g. Ability to communicate back and forth with Lambdasat during one pass timeframe (approximately $8 \mathrm{~min}$ of satellite available time in each pass).

h. Available test schemes:

Basic: text - simple data containing information for piracy activity up to $300 \mathrm{kB}$ (e.g. latitude, longitude, time, colour and name of the pirate vessel etc.).

Intermediate: audio - capability to talk to shore stations and convey by voice high-risk area picture and situational awareness. Provide the capability to the field officers (i.e. team leaders, guards on board vessels, captains) to communicate with operational headquarters at no extra or very low cost.

Advanced: AIS - receive and relay AIS signals from and to other vessels (up to 200 miles) (Mantzouris et al. 2015).

\section{Lambdasat Transmitter}

The Lambdasat transmitter is based on a Stensat radio beacon, a small FM transmitter capable of generating AX.25 unnumbered information (UI) packets at 1,200 bps AFSK and 9,600 bps FSK. The 9,600 bps FSK signal is compatible with G3RUH modulation. Power level is adjustable from 0 to $1 \mathrm{~W}$ operating on a single $5-\mathrm{V}$ supply. The specifications of the beacon are as follows:

- Bands available: $2 \mathrm{~m}, 70 \mathrm{~cm}$.

- Radio Frequency (RF) output power 0 to $1 \mathrm{~W}$ programmable.

- $\quad$ Operating voltage (Vdd) of $5.0 \mathrm{~V}$.

- Operating current of $650 \mathrm{~mA}$ in transmission.

- $40 \mathrm{~mA}$ when idle.

- $\quad$ Serial interface rate of 38.4 Kbaud UART 8 bit, no parity, one stop bit.

- Dimensions: $1.75 \times 3.10$ ” $\times 1.00$ "/44.45 $\times 78.74 \mathrm{~mm}$.

- Mass: approximately $50 \mathrm{~g}$.

- Digital input signal specifications: high signal > 0.7 Vdd.

- Low signal < $0.3 \mathrm{Vdd} ; 10 \mathrm{uA}$.

- Digital output signal specifications: high signal $>2.0 \mathrm{~V}$.

- Low signal $<0.4 \mathrm{~V} ; 3 \mathrm{~mA}$ sink.

- Mounting holes: 0.125 "; 4 - 40 mounting hardware.
- Frequency ranges: SRB-51-01 at $420-450 \mathrm{MHz}$ and SRB-51-02 at $144-148 \mathrm{MHz}$.

\section{Lambdasat Link Budget - Communication}

In order to set up the ground station, as well as to communicate with the satellite effectively, we analyzed and computed the link budget of it for the communication scheme. The central frequency that we are using is as indicated and above 437,462 MHz. Based on this frequency and taking into account orbital characteristics of the satellite, as well as losses through the medium and other parameters, we have calculated the link budget of Lambdasat in order to figure out how many decibels is the ratio of energy per bit rate for the noise figure. On the satellite a monopole antenna has been mounted, which has a length from 15 to $20 \mathrm{~cm}$ since there are three different very simple monopole antennas on two of the three dimensional axis of the satellite in the planes $x$ and $y$. These antennas serve to the purpose of communication with the ground station in the UOA.

As it is generally known link budget is a calculation that computes received power taking into account transmission power minus losses and plus all gains. This equation is as follows:

$$
\begin{aligned}
& \text { Received power }(\mathrm{dBw})= \\
& \text { transmission power }(\mathrm{dBw})+\text { gains }(\mathrm{dB})-\text { losses }(\mathrm{dB})
\end{aligned}
$$

Based on the above equation we have created a Microsoft ${ }^{\circledR}$ Excel spreadsheet that accumulates all the above factors containing each detail that is critical for our communication path. The calculation will show how much quantity of signal is going to be received on our ground station so as to finally decode the signal of the Lambdasat and receive AIS message as well as the piracy message.

As it has been noted in Schmidt (2015) and Lambdasat (2015), through the analysis of factors for link budget, we have calculated, using a Microsoft ${ }^{\circledR}$ Excel spreadsheet, the absolute energy per bit rate per noise for the Lambdasat. We have used as transmission power the maximum available requirement from the satellite power bus and, for satellite antenna beam width, we have used 360 degrees since the antenna is monopole. The gain of the antenna is around $6 \mathrm{~dB}$ whereas the diameter is only $1 \mathrm{~cm}$ (indicative value). On the other side for transmission antenna pointing losses from 0.5 up to 180 degrees, the communication margin changes only $5 \mathrm{~dB}$ approximately, which is acceptable. For the slant range of the satellite we have figured out that this is from 1,200 to $600 \mathrm{~km}$ 
approximately and for that reason we have played two different scenarios with minimum and maximum slant ranges when the elevation of the satellite is more than 5 degrees, which practically gives us the capability to start communicating from the ground station in the UOA. In the first maximum case we have a margin of $\mathrm{E}_{\mathrm{b}}$ over $\mathrm{N}_{\mathrm{o}} 26 \mathrm{~dB}$ (100 times the signal stronger from the noise) whereas in the second minimum distance of slant range we have $\mathrm{E}_{\mathrm{b}} / \mathrm{N}_{\mathrm{o}} 32 \mathrm{~dB}$, which practically means that the signal is 1,000 times stronger from the noise. In both cases, though, we know that our figures are acceptable for the communication of the Lambdasat with the ground station. Following our analysis and as known in the equations of link budget stemming from Schmidt (2015) and Lambdasat (2015), we have accumulated space losses as well as transmission line losses and system noise temperature. All these losses are being subtracted from the final collected energy level in order to give us the communication margin for the satellite. Ground station, as it will be analyzed next, comprises yagi UHF antennas of 42 elements with a gain that reaches $18 \mathrm{~dB}$. Pointing losses of the antenna are less than 3 degrees since there is automatic control and tracking of the antenna that follows through automatic software the change in azimuth and elevation of the satellite. Finally and for data rate of $1,200 \mathrm{bps}$, which is the data rate that our satellite is using in AFSK mode, we calculate using the Microsoft ${ }^{\circledR}$ Excel spreadsheets available that have been produced for this reason and is shown in Fig. 2. The final margin for communication with the satellite taking into account real-time orbital characteristics as well as worse and best-case scenarios is calculated to be in the range of 26 up to $32 \mathrm{dBW}$ with only $1 \mathrm{~W}$ of available power.

\section{PRELIMINARY ANALYSIS OF ACQUIRED ORBITAL DATA}

Experiments with Lambdasat and other micro and picosatellites were executed from March 2015 until August 2015. Via autotracking software, available on the ground station of the UOA, a number of picosatellites have been acquired and their data, analyzed. The commercial software used for tracking two-line elements (TLE) of the satellite is Orbitron or GPredict (giving same results), and NORAD site was the primary provider of TLE sets for the orbit of the satellite on a daily basis.

The first observation was that our satellite Lambdasat is having a Doppler difference of 8 to $10 \mathrm{kHz}$, when passing inbound and outbound respectively on a positive and negative effect. So, when approaching, the Doppler effect is $+10 \mathrm{kHz}$ where in the outbound it is $-10 \mathrm{kHz}$. This situation is influencing the communication in a maximum degree since normal CubeSats and microsatellites like FO-29, Cubebag1, Funcube and others, as those we have downloaded

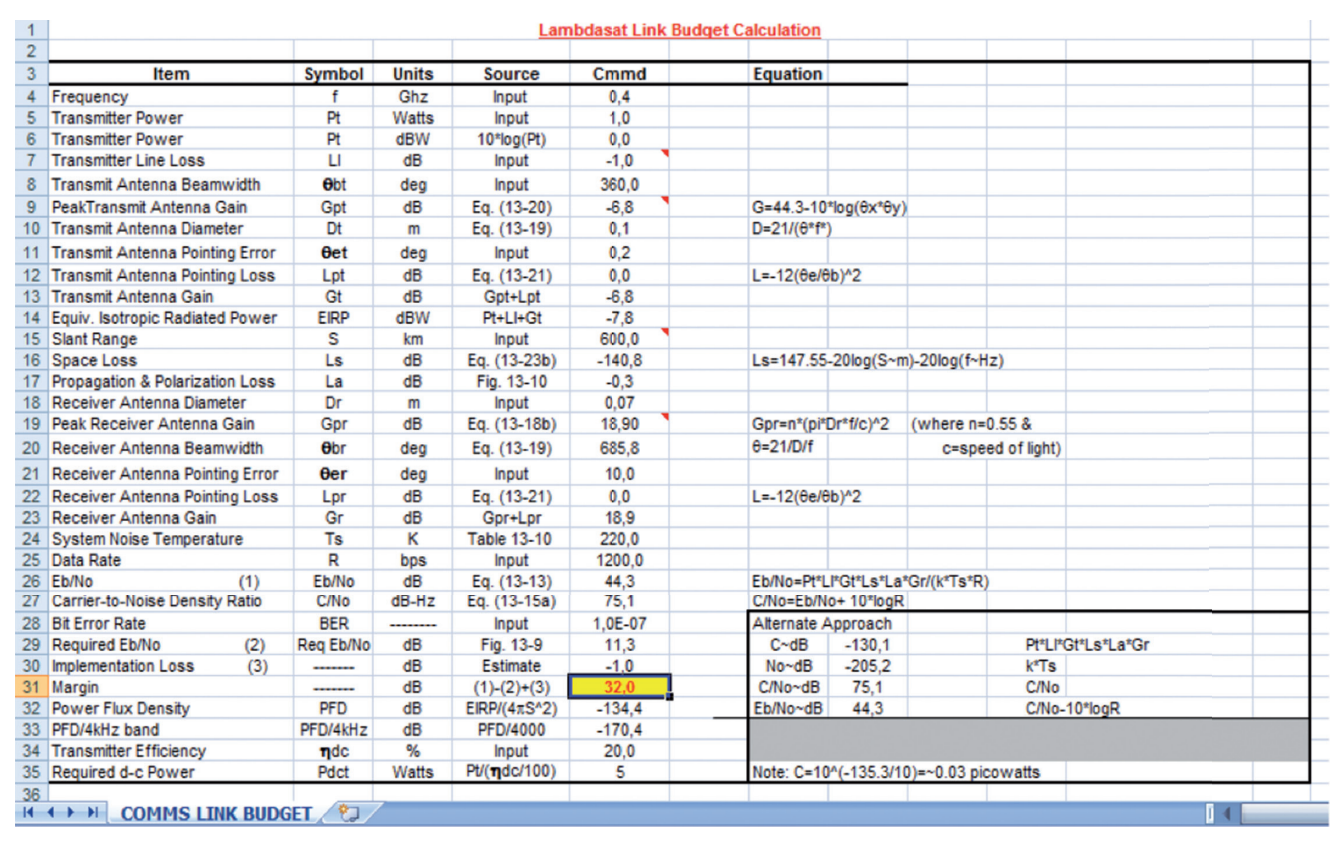

Figure 2. Link budget of Lambdasat using figures for the best-case scenario ( $32 \mathrm{~dB}$ ), which is minimum slant range and minimum losses. Worst-case scenario margin result is $26 \mathrm{~dB}$, which is still a good figure for communication link budget of the satellite with ground station. 
through our ground station, have a typical figure of 4 to $6 \mathrm{kHz}$. In accordance with the Doppler effect, function, and calculation, this is happening primarily due to the fact that the satellite is orbiting at a VLEO (lower than International Space Station) in $400 \mathrm{~km}$, and the satellite velocity is $7.669 \mathrm{~km} / \mathrm{s}$ (in accordance with calculations based on GPredict software and at March $\left.11^{\text {th }}\right)$. Date here is critical since the satellite does not have on board propulsion, and an orbital decay parameter is affecting its motion.

First series of acquired data from Funcube picosatellite, via the UOA ground station, were collected in July 2015. Analysis of all the characteristics listed next is going to be made in order to conclude what is the amount of quality data that the Lambdasat or a picosatellite like Funcube can send in order to define the space index metric for maritime security. If this space index be materialized (currently data is being collected from the ground station on a daily basis), then a measure of performance percent will be defined on how picosatellites can support the conduction of alert operations in maritime security arena. The elements of the data collection from the ground station for future analysis are:

- Time of pass of the picosatellite.

- Azimuth range.

- Elevation range.

- $\quad$ Altitude of flight.

- Inclination.

- Duration of pass.

- Duration of received signal.

- Signal strength.

- Cloud coverage.

- Rain.
- Temperature.

- Actual message received.

- Number of quality bytes received.

Analyzing all the above data we manage to measure the effectiveness and performance of metrics that will be created for the use of picosatellites in alerted maritime security operations.

\section{MICROPROPULSION IN PICOSATELLTES}

Based on findings from previous paper (Mantzouris et al. 2015) with picosatellite Tubesat, further investigation on applying micropropulsion to microsatellite buses is necessary, in view of increasing their lifetime (e.g. from one month to one year). Based on a state-of-the-art review conducted for all available electric micropropulsion systems, possible candidates have been identified in the range of few Watts providing thrust in the range of $\mathrm{mN}$.

Currently, a few research institutes and universities have communicated results in this research field. Table 4 and Fig. 2 present summarized findings of the state-of-the-art review, focusing on the performance characteristics of the various systems. The best available figure comes from the University of Kyoto (Japan), which has reported microwave electrothermal thruster power of 3.1 W capable of providing $4.3 \mathrm{mN}$ thrust (Table 4). This figure can be considered to be applied on a micro and pico (but not femto) satellite bus and sustain orbital path for over a year. Thus, the microwave electrothermal thrusters (MET) may be a viable solution for application in microsatellite buses.

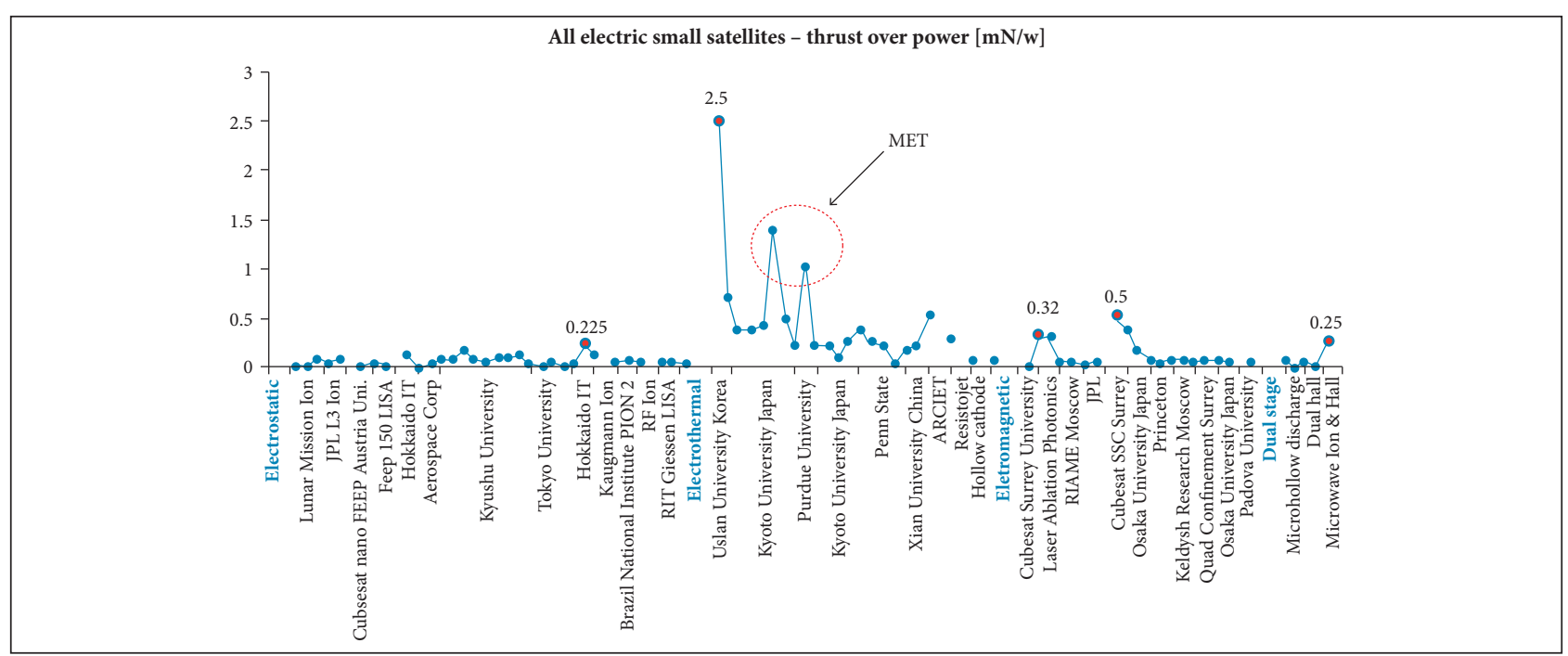

Figure 3. Micropropulsion thruster performance for various devices (thrust/power ratio). 
Finally, one can see in Fig. 3 and through detailed analysis that the best available figure for a micropropulsion system is being delivered from a MET, which has the capability of delivering a thrust/ power ratio that reaches almost 1.5 (the exact figure is 1.38). This is the best figure for a MET thruster provided by the University of Kyoto whereas all other types of electrothermal thrusters (more than 50 of them have been reviewed) are delivering much lower figures that are not acceptable for a micro/picosatellite mission.

Table 4. Summarized data for various organizations that currently undergo research towards the microwave electrothermal propulsion areas.

\begin{tabular}{|c|c|c|c|c|c|c|c|c|}
\hline \multicolumn{9}{|c|}{ Micro/nano/pico - MET comparisons } \\
\hline $\begin{array}{l}\text { Power } \\
\text { [W] }\end{array}$ & $\begin{array}{l}\text { Thrust } \\
\text { [mN] }\end{array}$ & $\begin{array}{c}\text { Specific } \\
\text { Impulse [s] }\end{array}$ & $\begin{array}{c}\text { Thruster } \\
\text { efficiency [\%] }\end{array}$ & Propellant & $\begin{array}{l}\text { Propellant } \\
\text { flow rate }\end{array}$ & $\begin{array}{c}\text { Frequency } \\
\text { [GHz] }\end{array}$ & Date & Institution \\
\hline 3 & $\uparrow 1.8-5.6 \%$ & - & - & $\mathrm{Ar}$ & - & 4 & \multirow{8}{*}{2011} & \multirow{6}{*}{ Kyoto (NASA 2015) } \\
\hline 6 & $\uparrow 2.8-12.3 \%$ & - & - & $\mathrm{Ar}$ & - & 4 & & \\
\hline 3 & 1.08 & 62 & 10 & $\mathrm{Ar}$ & 60 - magnet & 4 & & \\
\hline 3 & 1.03 & 59 & 9.2 & $\mathrm{Ar}$ & 60 - no magnet & 4 & & \\
\hline 6 & 1.23 & 70 & 6.8 & $\mathrm{Ar}$ & 60 - magnet & 4 & & \\
\hline 6 & 1.11 & 64 & 5.6 & $\mathrm{Ar}$ & 60 - no magnet & 4 & & \\
\hline 6 & 0.51 & 250 & 10.1 & $\mathrm{He}$ & $2-70$ & 4 & & \multirow{2}{*}{ Kyoto (Lambdasat 2015) } \\
\hline 6 & 0.51 & 375 & 10.1 & $\mathrm{H}_{2}$ & $2-70$ & 4 & & \\
\hline 6 & $0.2-1.4$ & $50-80$ & $2-12$ & $\begin{array}{c}\mathrm{Ar}+5 \% \mathrm{~N}_{2} \\
\text { and } \mathrm{H}_{2}\end{array}$ & $10-60$ & 4 & 2009 & Kyoto (Schmidt 2015) \\
\hline 6 & 1.4 & 80 & 8.7 & $\begin{array}{c}\mathrm{Ar}+5 \% \mathrm{~N}_{2} \\
\text { and } \mathrm{H}_{2}\end{array}$ & 60 & 2 and 4 & 2008 & $\begin{array}{c}\text { Kyoto } \\
\text { (Anderson and Sojka 2009) }\end{array}$ \\
\hline \multicolumn{7}{|c|}{ With $4 \mathrm{GHz}$, plasma is little affected; with $10 \mathrm{GHz}$ and shorter chamber, thrust performance is improved } & \multirow{3}{*}{2007} & $\begin{array}{c}\text { Kyoto } \\
\text { (Amateur Radio in Space 2015) }\end{array}$ \\
\hline 3 & 1.2 & 66 & 12 & $\mathrm{Ar}$ & - & 4 & & \multirow{2}{*}{$\begin{array}{l}\text { Kyoto (Bordetsky and } \\
\text { Mantzouris 2011) }\end{array}$} \\
\hline 6 & 1.4 & 79 & 8.7 & $\mathrm{Ar}$ & - & 4 & & \\
\hline 6 & 1.4 & 80 & 8.7 & $\begin{array}{l}\mathrm{Ar}+5 \% \\
\mathrm{~N}_{2} \text { and } \mathrm{H}_{2}\end{array}$ & $10-60$ & 4 & 2008 & Kyoto (Sølvhøj 2002) \\
\hline 10 & $2.5-3.5$ & $130-180$ & - & - & $2 \mathrm{mg} / \mathrm{s}$ & $1-25$ & \multirow{2}{*}{2006} & Kyoto (Wertz and Larson 2005) \\
\hline 5 & 1.1 & 73 & 4.2 & $\mathrm{Ar}$ & $10-50$ & 4 & & Kyoto Abaimov et al. 2013) \\
\hline 4 & 2 & 136 & 12 & $\mathrm{Ar}$ & $1.5 \mathrm{mg} / \mathrm{s}$ & 4 & 2005 & \multirow{2}{*}{$\begin{array}{l}\text { Kyoto (Takao et al. 2008) } \\
\text { Kyoto (Seller 2004) }\end{array}$} \\
\hline 3.1 & 4.3 & 320 & - & Ar & 280 & 4 & 2004 & \\
\hline 100 & $3-6$ & $30-80$ & $50-78$ & $\begin{array}{l}\mathrm{He}, \mathrm{N}_{2} \text {, and } \\
\text { ammonia }\end{array}$ & $2-20 \mathrm{mg} / \mathrm{s}$ & - & 2004 & Penn State Takahashi et al. 2007) \\
\hline 20 & $0.2-4.5$ & $169-197$ & - & $\mathrm{He}$ & $2.15 \mathrm{mg} / \mathrm{s}$ & 14.5 & 2007 & Penn State (Takao and Ono 2004) \\
\hline 200 & & $321-434$ & $6.9-75$ & $\begin{array}{l}\text { Ammonia } \\
\text { and hydrazine }\end{array}$ & - & 8 & 2001 & Penn State (Takao et al. 2007) \\
\hline $100-250$ & $15-90$ & $190-315$ & - & $\mathrm{N}_{2} \mathrm{H}_{3}$ & - & 8 & 2011 & Penn State (Takahashi et al. 2009) \\
\hline 2.94 & - & - & - & $\mathrm{He}$ & - & 30 & 2011 & Penn State (Kawanabe et al. 2011) \\
\hline $100-300$ & $20-120$ & $450-650$ & $34-50$ & $\mathrm{He}$ & $4.09-6.14 \mathrm{mg} / \mathrm{s}$ & - & \multirow{2}{*}{2008} & \multirow{2}{*}{ Xian (Takao and Ono 2006a) } \\
\hline 70 & 15 & 340 & - & $\mathrm{He}$ & - & - & & \\
\hline 120 & $25.5 \times 10^{6}$ & 5,758 & 61.3 & $\mathrm{~N}_{2} \mathrm{H}_{4}$ & $4.4 \mathrm{mg} / \mathrm{s}$ & - & 2011 & Xian (Takahashi et al. 2008) \\
\hline $1-5$ & $2.5-3.5$ & $130-180$ & - & $\mathrm{Xe}$ and $\mathrm{Ar}$ & 80 & - & 2011 & $\begin{array}{l}\text { Korea Ulsan University } \\
\text { (Takao et al. 2011) }\end{array}$ \\
\hline 150 & $40-75$ & $70-200$ & - & $\mathrm{He}$ and $\mathrm{N}_{2} \mathrm{O}$ & $0.025 \mathrm{mg} / \mathrm{s}$ & 7.5 & 2004 & Princeton (Takao and Ono 2006b) \\
\hline
\end{tabular}




\section{CONCLUSION}

This brief analysis aims to inform the reader in an alternative way to support maritime security operations. The micro and picosatellites are yet to prove their effectiveness in the operational theatre, though cost reduction is considered to be the driving force behind any advancement in this field in the following years.
Cost-benefit analysis of the proposed picosatellite system is under stuffing and in the process of being executed in order to acquire preliminary results on how these solutions can be implemented in a maritime security context. Nevertheless, it remains unclear how these solutions will affect maritime security operations in practice, an issue that has to be examined with further analysis and experimentation.

\section{REFERENCES}

Abaimov MD, Sinha S, Bilén SG, Micci MM (2013) CubeSat Microwave Electrothermal Thruster (CHMET). Proceedings of the 33rd International Electric Propulsion Conference. The George Washington University; Washington, USA.

Amateur Radio in Space (2015) Communication satellites; [accessed 2015 Nov 08]. http://www.amsat.org/amsat-new/satellites/ satInfo. php?satID=83\&retURL=satellites/futures. php

Anderson P, Sojka J (2009) Development of a cubesat picosatellite. Utah State University Undergraduate Research Showcase; Logan, USA.

Bordetsky A, Dougan A (2008) Networking and collaboration on maritime-sourced nuclear threats. Proceedings of 6th Security Workshop; Washington, USA.

Bordetsky A, Mantzouris G (2011) Modelling of pico satellite network applications to maritime interdiction operations. Proceedings of the 16th International Command \& Control Research \& Technology Symposium; Quebec, Canada.

Bordetsky A, Netzer D (2010) Testbed for tactical networking and collaboration. International C2 Journal 3(4):1-30.

Gordon GD, Morgan WL (1993) Principles of communication satellites. New Jersey: Wiley-Interscience.

Kawanabe T, Takahashi T, Takao Y, Eriguchi K, Ono K (2011) Microwave-excited microplasma thruster with applied magnetic field. Proceedings of the 32nd International Electric Propulsion Conference; Wiesbaden, Germany.

Lambdasat (2015); [accessed 2015 Nov 08]. www.lambdasat.com

Mantzouris G, Papadopoulos P, Nikitakos N, Manso M, Markarian G (2015) Exploring the application of picosatellites for maritime security. Proceedings of the 2Oth International Command and Control Journal/ Conference; [accessed 2015 Nov 09]. http://www.dodccrp-test. org/s/067-s1wl.pdf

NASA (2015) Official NASA announcement for Lambdasat successful launch; [accessed 2015 Oct 10]. http://www.nasa.gov/mission_ pages/station/research/experiments/1865.html

Schmidt M (2015) Pico satellite activities of the University of Wuerzburg; [accessed 2015 Nov 08]. http://www.nanosat.jp/1st/ files/10th.AM/Presentation_Marco-Schmidt.pdf

Seller JJ (2004) Understanding space: an introduction to Astronautics. 2nd ed. New York: McGraw-Hill.
Sølvhøj J (2002) Onboard computer for picosatellite. Oersted: Technical University of Denmark.

Takahashi T, Takao Y, Eringuchi K, Ono K (2007) Numerical analysis and experiments of a microwave excited microplasma thruster. Proceedings of the 30th International Electric Propulsion Conference; Florence, Italy.

Takahashi T, Takao Y, Eriguchi K, Ono K (2008) Microwave excited microplasma thruster: a numerical and experimental study of the plasma generation and micronozzle flow. J Phys Appl Phys 41(19):194005. doi: 10.1088/0022-3727/41/19/194005

Takahashi T, Takao Y, Eriguchi K, Ono K (2009) Numerical and experimental study of microwave-excited microplasma and micronozzle flow for a microplasma thruster. Phys Plasmas 16(8): 083505. doi: $10.1063 / 1.3205889$

Takahashi T, Takao Y, Ichida Y, Eriguchi K, Ono K (2011) Microwaveexcited microplasma thruster with helium and hydrogen propellants. Phys Plasmas 18(6):063505. doi: 10.1063/1.3596539

Takao Y, Eriguchi K, Ono K (2007) A miniature electrothermal thruster using microwave-excited microplasmas: thrust measurement and its comparison with numerical analysis. J Appl Phys 101:123307. doi: $10.1063 / 1.2749336$

Takao Y, Ono K (2004) Development and modeling of a microwave excited microplasma thruster. Proceedings of the 4Oth AIAA/ASME/SAE/ASEE Joint Propulsion Conference and Exhibit; Fort Lauderdale, USA.

Takao Y, Ono K (2006a) A miniature electrothermal thruster using microwave excited plasmas: a numerical design consideration. Plasma Sources Sci Technol 15(2):211-277. doi: 10.1088/09630252/15/2/006

Takao Y, Ono K (2006b) Performance testing of a miniature electrothermal thruster using microwave excited microplasmas. Proceedings of the 42nd AIAA/ASME/SAE/ASEE Joint Propulsion Conference and Exhibit; Sacramento, USA.

Takao Y, Takahashi T, Eriguchi K, Ono K (2008) Microplasma thruster for ultra small satellites: plasma chemical and aerodynamical aspects. Pure Appl Chem 80(9):2013-2023. doi: 10.1351/ pac200880092013

Universität Würzburg (2015) Pico satellite activities of the University of Wuerzburg; [accessed 2015 Nov 08]. www7.informatik.uniwuerzburg.de

Wertz JR, Larson WJ (2005) Space mission analysis and design. 3rd ed. Portland: Microcosm. 